\title{
THE PRESENCE OF A DISTINCTIVE INSECT HERBIVORE FAUNA DURING THE
} LATE PALEOZOIC

\author{
LABANDEIRA, Conrad C., Smithsonian Institution, National Museum of Natural History, \\ Department of Paleobiology, MRC-121, Washington, DC 20560, U.S.A.
}

It has been assumed that insect herbivory was minimally developed or absent during the Late Carboniferous and Permian, and that ecologically significant herbivore dietary guilds and functional feeding groups did not arise until the Triassic or even later. While this canonical view remains unchallenged, recent documentation from wetland environments in equatorial coal-swamp floras from Euramerica demonstrate that a diverse community of insect herbivores were partitioning plant tissues in major and essentially modern ways. These data, coupled with Permian ecological replacement of the Paleozoic Insect Fauna by the Modern Insect Fauna and the devastation that the end-Permian extinctions had on Paleozoic insect clades, suggest that modern (Mesozoic + Cenozoic) insect clades re-evolved the functional feeding groups and broad dietary guilds that had existed during the Late Paleozoic.

The data originates from the anatomically-preserved, specimen abundant, and floristically diverse, Late Pennsylvanian Calhoun Coal-Ball Flora of the Illinois Basin. It centers on the insect associates of the dominant arborescent element, the tree fern Psaronius, and to a lesser degree the subdominant seed fern tree Medullosa. Exhaustive examination of coalball material indicates that Psaronius harbored insect associates as diverse as its modern marattialean fern descendants, including stem and root-mantle borers, gallers, piercer-andsuckers, folivores, and sporangia-feeders, although leaf miners have not been recorded. However, presumptive but tentative evidence does indicate that the coexisting Medullosa bore a leaf miner, corroborated by occurrences on the same foliage in somewhat younger and older Euramerican compression floras. Additionally, tissue damage in coal-ball and compression floras indicate that Medullosa contained external foliage feeders that included skeletonizers and margin- and center-feeders, and a piercer-and-sucker targeting microsporangial tissues inside a bell-shaped pollen organ.

The extent that Psaronius organs and tissues were partitioned by insect herbivores is instructive for understanding how insect/plant interactions occurred on a single, regionally pervasive, host plant during the Late Pennsylvanian. Mature Psaronius trees were about 10 meters tall in a closed-canopy forest on better-drained portions of peat-dominated swamps. Psaronius contained a central trunk that was buttressed basally by a root mantle. Indurated tissues in this root mantle, as well as parenchymatous underground roots penetrating the peat, were bored by miniscule oribatid mites. The interstelar parenchyma of the central stem in the trunk was bored by an insect ecologically analogous to certain modern cockroaches. Within the tree crown, considerable herbivore activity occurred on the major rhachises and on frond pinnules. The rhachises were attacked by a paleodictyopteran piercer-and-sucker sequestering xylem and phloem tissue by external styletal probes. Internal ground parenchyma of the rhachis was consumed and galled by a tunnelling endopterygote insect. These galls exhibit nutritive tissue deployed as hyperplasic tufts of secondary parenchyma that encapsulate a frass-littered central lumen. Coprolites occurring individually in the peat litter and containing exclusively foliar material from Psaronius fronds indicate that external foliage feeders, probably protorthopteran insects, were consuming whole pinnules. Similar evidence for spore consumption is provided by coprolites consisting of only spores from synangia located on the undersides of the same Psaronius pinnules. Thus, in addition to evidence for the functional feeding groups of boring, piercing-and-sucking, galling, external foliage feeding, and spore consumption, there is complementary evidence for the targeting of the following live plant tissues: stem and rhachis parenchyma; rhachis xylem and phloem; pinnule epidermis, palisade tissue and mesophyll; various sporangial tissues; and trunk epidermal scales.

A separate ecological dimension is now attached to the unique Paleozoic Insect Fauna. It is appearing less likely that this distinctive assemblage of insect taxa was fundamentally detritivorous. In fact, it is quite likely that modern-style herbivore exploitation of live plant tissues was well-established during the Late Pennsylvanian, 300 million years ago. 